\title{
Antimicrobial activity of turmeric (Curcuma longa) extract and its potential use in fish preservation
}

\author{
S. Nath ${ }^{1}$, P. Chatterjee ${ }^{2}$, S. Chowdhury ${ }^{1 *}$, N. Ray ${ }^{1}$ and S. Mukherjee ${ }^{2}$
}

${ }^{1}$ Department of Fish Processing Technology, Faculty of Fishery Sciences, West Bengal University of Animal and Fishery Sciences, Kolkata - 700 094, West Bengal, India; ${ }^{2}$ Department of Biotechnology, Maulana Abul Kalam Azad University of Technology, Nadia - 741 249, West Bengal, India

\begin{abstract}
Fish is one of the major sources of nutrients. However, because of its perishable nature, it begins to deteriorate as soon as they leave the water. So, preservation is required to extend its shelf life. The widely used chemical preservatives harm both human and fish. So, uses of natural, cheap, harmless, and efficient preservatives are in high demand nowadays. Turmeric (Curcuma longa) possesses excellent antibacterial, antifungal, immunostimulatory, and anti-insecticidal activities. It is found to have antibacterial activity against a wide range of bacteria causing spoilage to fish. It also inhibits the growth of some fungi associated with fish deterioration. Turmeric can boost the immunity of the fish, which makes them resistant towards spoilage microorganisms, and reducing the mortality rate efficiently. Insect manifestation, a big problem in the drying process, can be decreased with the use of turmeric. Turmeric has shown its activity while being applied as feed additive or by coating externally. The addition of turmeric during salt drying process also increases the shelf life of fish. Turmeric has a great potential to be used as a preservative in food science that need to be further explored in future.
\end{abstract}

Key words: Antimicrobial activity, Curcumin, Fish preservation, Turmeric

\section{Highlights}

- Turmeric is a natural antimicrobial compound which can be used either alone or in combination with mild physicochemical treatments and low concentrations of traditional chemical preservatives, to efficiently extend shelf life and food safety.

- Turmeric acts as a potential natural preservative for domestic purposes as well as commercial food industries and distribution chains.

- Turmeric (Curcuma longa) possesses excellent antibacterial, antifungal, immunostimulatory, and anti-insecticidal activities.

\section{Introduction}

India ranks second in aquaculture contributing $7 \%$ of global fish production with a fish diversity of $10 \%$ worldwide (Mukherjee et al., 2020). Fish is an excellent source of high nutritional value protein and contains omega-3 polyunsaturated fatty acids (PUFA), especially, eicosapentaenoic acid (EPA) and docosahexaenoic acid (DHA) (Mei et al., 2019), which are essential for normal growth and development and may prevent coronary artery disease, hypertension, diabetes, arthritis, inflammatory and autoimmune disorders, and cancer (Bakli et al., 2020). Fish is also a good source of vitamins like $A, D, B_{6}$, and $B_{12}$. Minerals such as iron, zinc, iodine, selenium, potassium, sodium, etc. are also present in fish (Bakli et al., 2020). Thus, fish can meet up the daily requirement of 200 to $500 \mathrm{mg}$ of omega3 PUFA as well as other vital nutrients as directed by World Health Organization (Mei et al., 2019).

Fish is perishable in nature due to its highwater content. The $\mathrm{pH}$ of fish is in the range of 
6.8 to 7 which is safe for human consumption (Farid et al., 2014). Upon storage of fish, pH starts to increase due to the production of volatile amines and finally crosses the limit of acceptability of safe consumption of fish leading to spoilage. Due to the low acidic and highly perishable nature of fish, the food spoilage bacteria can grow easily which leads to spoilage. The extent of microbial spoilage depends on the microbial load, available metabolites in tissue and storage conditions, and species concern (Farid et al., 2014). The pathogens associated with the fish during harvesting, handling, and processing lead to deterioration which is expressed by a strong odor, texture changes with slime production, and gross discoloration, thus fish being rejected by consumers (Farid et al., 2014). One of the major concerns in food industries in tropical countries like India is the contamination by food spoilage and pathogenic bacteria causing foodborne diseases (Farid et al., 2015). Moreover, higher temperature accelerates oxidation and hydrolysis of fats, protein denaturation and autolysis which are associated with microbial spoilage (Farid et al., 2014). Among the changes of chemicals associated with fish deterioration, the low molecular weight nitrogenous biogenic amine (BA) compound such as histamine and tyramine, are produced due to the decarboxylation of the amino acids by decarboxylase enzyme of spoilage bacteria present in fish. The higher level of BA leads to several symptoms like nausea, vomiting, burning sensation in the mouth, respiratory disease, itching, headache, allergy, heart palpitation, hypertension, etc. (Chong et al., 2011).

Present-day food preservation is viewed as a 'convenience' product as well as a key to ensure the availability of food as a vital benefit. Consumers, nowadays, demand natural but effective preservation of food free of potential health risks. This shift in consumer preference for minimally processed foods has led to the increasing consumption of precooked food, prone to temperature abuse, thus increasing the likelihood of food-related illness and product spoilage (Nath et al., 2017). Therefore, to harmonize consumer demands with the necessary safety standards, traditional means of controlling microbial spoilage and hazards in foods are being replaced using biological, natural, and organic antimicrobial compounds such as turmeric, either alone or in combination with mild physicochemical treatments and low concentrations of traditional chemical preservatives. This approach of food preservation is an efficient way of extending shelf life and food safety through the inhibition of spoilage and pathogenic bacteria without altering the nutritional quality of raw materials and food products (Nath et al., 2014).

\section{Fish preservation}

During storage, the freshness of fish gradually deteriorates with degradation of protein and fat content of the fish. Such changes are primarily accelerated due to the high moisture content in fish facilitating microbial growth and spoilage, enzymatic degradation, high ambient temperature, and unhygienic handling practices (Nwaigwe, 2017). Fish spoilage can be caused by three main mechanisms: enzymatic degradation, oxidative rancidity of fat and microbial spoilage. Implementation of food processing and microbiological food safety standards has diminished the likelihood of food-related illness and product spoilage, although complete elimination is not possible. The increasing consumption of precooked food especially seafood, prone to temperature abuse, and the import of raw seafood from developing countries, results in the outbreak of foodborne illness (Nath et al., 2014). In Europe, morbidity from foodborne illness is second only to respiratory diseases and an estimated 50,000 to 300,000 cases of acute gastroenteritis per million populations are encountered every year (Nath et al., 2013). Bacterial pathogens including Salmonella, Campylobacter jejuni, Escherichia coli 0157:H7, Listeria monocytogenes, Staphylococcus aureus, and Clostridium botulinum are found associated with such outbreaks (Nath et al., 2014). 
Therefore, the preservation of food in sound and safe condition continues to be an ongoing challenge for human.

Drying, salting, and fermentation have long been adopted by human as a traditional method of food preservation. But the problem associated with the sun drying process is the infestation by insects followed by microbial spoilage of fish (Farid et al., 2015). Low temperature such as chilling and icing are practiced for delaying the enzymatic degradation and bacterial spoilage, thus, retention of nutritional quality takes place (Nath et al., 2019); but psychrotolerant Gramnegative Pseudomonas sp. and Shewanella sp. may survive to cause quality deterioration.

Preservation by modified atmospheric packaging (MAP) restricts the growth of aerobic bacteria but allows the growth of Photobacterium phosphoreum and lactic acid bacteria (LAB). Some Gram-negative fermentative bacteria like $P$. phosphoreum and psychrotolerant Enterobacteriaceae can grow in frozen product and under refrigeration storage, causing spoilage (Ghaly et al., 2010). Even after acidification or addition of preservative, some lactobacilli and yeast can grow. Some halophilic and halotolerant bacteria and filamentous fungi cause spoilage in saltcured and dried fish (Sivaraman et al., 2015). Even after thermal sterilization or canning process, spores of Bacillus stearothermophilus can germinate and cause spoilage in canned fish and fishery products (Mohan, 2018). Recent advances to preserve fishes with antibiotics to reduce the chances of microbial spoilage are although effectively successful, but the development of antibiotic-resistant bacterial strains is of great concern and difficult to control.

Additives and preservatives with antimicrobial and antioxidant properties play an important role in ensuring food safety. Many antimicrobial agents such as sulfites, nitrites, organic acids, and several antioxidants (butylated hydroxyanisole, butylated hydroxytoluene, and butylhydroxyquinone) have been used since long to preserve fish from microbial spoilage and oxidative rancidity. Despite the high potential for preservation, some restrictions are there in the application of these synthetic preservatives due to potential toxicological effects (Viji et al., 2017). Thus, the application of natural preservatives such as turmeric is a boon to the food industry.

\section{Turmeric}

Historical evidences and nomenclature: The earliest documentation of the use of the medicinal plant, turmeric, was in Rig-Veda, possibly written in between 4500-1600 BC (Krup et al., 2013). The Atharvaveda of India along with other Sanskrit pieces of the literature revealed the use of turmeric in ancient India due to its nutritional value (Kumar et al., 2011). At 700 AD turmeric reached China (Krup et al., 2013) and Marco Polo mentioned, turmeric as Indian saffron (Bhowmik et al., 2009) during his visit to India and China in 1280 (Rathaur et al., 2012). Evidence of turmeric was found in East Africa and West Africa at around $800 \mathrm{AD}$ and $1200 \mathrm{AD}$ respectively, whereas turmeric was introduced in Arabian countries in the $10^{\text {th }}$ century (Kumar et al., 2011). Although Arabian traders introduced turmeric in England around the $13^{\text {th }}$ century, after the voyage of a Portuguese sailor, Vasco da Gama in the $15^{\text {th }}$ century, turmeric was truly introduced to the west (Rathaur et al., 2012).

Turmeric has a wide nomenclature in different regions. The recent name 'Curcuma' came from Arabic Kurkum and Hebrew Karkom, which stands for yellow; and the 'Longa' came due to the elongated shape of the rhizome. The botanist, Valeton, coined the term Curcuma domestica as it is referred to as domestic plant. Interestingly, the English term 'turmeric' came from Sanskrit, which means 'yellow' due to its yellow-colored rhizome (Kumar et al., 2011).

Turmeric tree is 3 to 5 feet long having pointed, oblong leaves and funnel-shaped yellow flowers with a yellowish and thick rhizome (Kumar et al., 2011; Sodamola et al., 2016). The dried primary bulb and secondary 
lateral rhizomes are collected, cleaned, boiled, and finally dried to get commercial powder turmeric (Sodamola et al., 2016). In subtropical regions and tropical countries like India, turmeric is widely cultivated.

Uses of turmeric: Turmeric is a popular folk medicine throughout the globe since the early days. In Uttar Pradesh, India, the rhizome of turmeric is widely used to treat cough and cold; the tribes of Jhalda, Purulia, West Bengal also apply the paste of rhizome of turmeric as skin fairness agent (Krup et al., 2013).

Several beneficial attributes like antibacterial, antiviral, antifungal, antioxidant, anti-arthritic, anti-tumor, antithrombotic, nematocidal, antihepatotoxic, anti-mutagenic, anti-choleretic and even antivenom activities make turmeric indispensable in medicine, pharmaceutical, and food industry. Turmeric has a strong influence as antispasmodic, cardiovascular, diuretic, carminative, astringent, cholagogue, digestive, appetizer, stimulant, and vulnerary property (Bhowmik et al., 2009). Lesser prevalence of Alzheimer's disease is documented in regions with high consumption of turmeric like India (Yadav et al., 2017). Turmeric improves the function of the small intestine, digestion, and metabolism by stimulating the production of various digestive enzymes involving in the process (Sugiharto et al., 2011). Arunkumar et al. (2016) reported that the hexane and ethanol extract of turmeric showed an inhibitory effect against 13 pathogenic bacteria. Gram-positive bacteria have enhanced interaction between the antimicrobial active compound of turmeric curcumin and the structural lipoproteins made them sensitive to turmeric than Gram-negative bacteria (Mukhtar and Ghori, 2012). Septiana et al. (2017) pointed out that endophytic symbiotic fungi of turmeric could inhibit histamine forming bacteria in fish; thus $5 \%$ of a turmeric extract has an inhibitory effect of histamine producing bacteria.

Chemical composition of turmeric: In 1815, curcumin was first isolated by Vogel and
Pelletier as a 'yellow coloring matter' from rhizomes of Curcuma longa and named it curcumin and in 1973 chemical structure of turmeric was determined by Roughly and Whiting (Amalraj et al., 2017). Curcumin exists in two tautomeric forms; keto and enol; the enol form is energetically more stable both in the solid phase and in solution than the keto form (Akram et al., 2010). Due to hydrophobic nature, turmeric is soluble in non-polar solvent like oil, dimethylsulfoxide, acetone, and ethanol but partly soluble or insoluble in polar solvent like water (Amalraj et al., 2017). The ethanolic extracts showed better results than the aqueous extract because organic solvent dissolves more organic molecules resulting in the release of higher active antimicrobial components (Mukhtar and Ghori, 2012).

Turmeric powder contains $6.3 \%$ protein, $69.4 \%$ carbohydrate, $5.1 \%$ lipid, $13.1 \%$ moisture, $3.5 \%$ mineral and $5 \%$ curcuminoids. Curcuminoids include curcumin (diferuloyl methane), demethoxycurcumin, and bisdemethoxycurcumin (Mooraki et al., 2019). Curcumin (3 to 4\%) is responsible for the yellow color of turmeric having maximum beneficial attributes (Akbik et al., 2014). In India, mainly two types of turmeric are cultivated viz. 'Madras' (2\% curcumin, 2\% volatile oil, having bright, light, and intensified yellow color) and 'Alleppy' (4 to 7\% curcumin, 3.5 to $5.5 \%$ volatile oil, with orange-yellow flesh color) (Gopinath and Karthikeyan, 2018).

There are several phenolic compounds present in turmeric such as 1-hydroxy-1, 7-bis (4-hydroxy-3-methoxyphenyl)-(6E)-6-heptene3, 5-dione; 1, 7-bis (4-hydroxyphenyl)-1,4, 6heptatrien-3-one; 1-(4- hydroxy-3, 5dimethoxy phenyl) - 7 - ( 4 - hydroxy-3methoxyphenyl)-(1E, 6E)-1, 6-heptadiene-3, 4dione; 1-(4 hydroxy-3-methoxyphenyl-5-(4hydroxyphenyl)-penta-(1E, 4E)-1, 4-dien-3one; 1-(4-hydroxy-3-methoxyphenyl)-7-(3, 4dihydroxyphenyl)-1, 6-heptadiene-3, 5-dione and 1, 5-bis (4-hydroxy-3-methoxyphenyl)penta-(1E, 4E)-1, 4-dien-3-one (Niranjan and Prakash, 2008). These phenolic compounds penetrate into the bacterial cell after destroying 
the cell wall and affect their metabolism (Antunes et al., 2012). Some other compounds are also found such as curlone, alphaturmerone, beta-turmerone, terpinolene, alphaphellandrene, curcumadiol, labda-8 (17)-diene15, 16-dial and three acidic polysaccharides named Ukon A, B and C. They contain Larabinose, D-xylose, D-galactose, D-glucose, L-rhamnose, D-galacturonic acid following ratios; Ukon A (12:4:12:1:4:10), Ukon B $(12: 4: 12: 1: 2: 4)$ and Ukon C (8:3:614:2:3). Whereas another polysaccharide Ukon $D$ has different composition containing L-arabinose, D-galactose, D-glucose, and D-mannose (1:1:12:2). Turmerin (soluble peptide part) has amino acids aspartic acid/asparagine, glutamic acid/glutamine, serine, glycine, arginine, proline, alanine, tyrosine, valine, methionine, leucine, isoleucine, and phenylalanine in a ratio of $1: 2: 3: 8: 1: 1: 1: 3: 2: 6: 3: 4: 5: 3$ (Niranjan and Prakash, 2008). Ikpeama et al. (2014) reported that turmeric contains phytochemicals such as, $1.08 \%$ tannin, $0.76 \%$ alkaloid, $0.82 \%$ phytic acid, $0.45 \%$ saponin, $0.03 \%$ sterol, $0.08 \%$ phenol and $0.40 \%$ flavonoid. Saponin, flavonoid and tannin have antioxidant properties; flavonoid has anti-inflammatory, anti-allergic, antioxidant and health-promoting activities; tannin has antimicrobial, antisecretolytic, anti-irritant, antiphlogistic, antiparasitic, and anticancer properties; saponin has anti-inflammatory activity, cholesterollowering, and anti-fungal properties.

\footnotetext{
Antibacterial effects of turmeric in fish preservation: Turmeric has antibacterial properties that help to increase the shelf life of fish and fishery products by delaying the microbial spoilage and prevent diseases caused by infectious pathogens. The antibacterial study on aqueous extract of $C$. longa rhizome showed the MIC (minimum inhibitory concentration) values as 4-16 $\mathrm{g} / \mathrm{L}$ and $\mathrm{MBC}$ (minimum bactericidal concentration) values as $16-32 \mathrm{~g} / \mathrm{L}$ against Klebsiella pneumoniae ATCC 10031, Staphylococcus epidermidis ATCC 12228, E. coli ATCC 25922 and S. aureus ATCC
}

25923 (Moghadamtousi et al., 2014). The hexane and methanol extracts of $C$. longa have an antibacterial effect against 13 bacteria namely Vibrio harveyi, V. alginolyticus, $V$. vulnificus, $V$. parahaemolyticus, $V$. cholerae, Bacillus subtilis, B. cereus, Aeromonas hydrophila, Streptococcus agalactiae, Staphylococcus aureus, S. intermedius, S. epidermidis, and Edwardsiella tarda (Lawhavinit et al., 2010). Even, curcumin has inhibitory activity against methicillin-resistant $S$. aureus strains (MRSA) having MIC value of $125-250 \mu \mathrm{g} / \mathrm{mL}$ by inhibiting the transcription of the mecA gene, so that the expression of PBP $2 \alpha$ proteins get decreased (Mun et al., 2014); thus, MRSA becomes sensitive towards $\beta$ lactam antibiotics such as -penicillin and methicillin. The study on S.aureus, E.coli, and B.subtilis demonstrated that curcumin binds to Fts $Z$ filament, decreasing the assembly of Fts $Z$, suppressing $\mathrm{Z}$ ring formation, hence prokaryotic cell division get disturbed (Kaur et al., 2010; Teow et al., 2016). Turmeric oil has inhibitory activity against $B$. subtilis, B. coagulans, B. cereus, S. aureus, Escherichia coli, and Pseudomonas aeruginosa (Moghadamtousi et al., 2014). Moreover, Suvarna et al. (2014) reported that turmeric had significant antibacterial activity against Enterococcus faecalis. In fish and fishery products, enterotoxins produced by $S$. aureus causes gastroenteritis after consumption which may be inhibited by turmeric as binding of curcumin with the bacterial cell wall leads to the damage of cell wall and cell membrane causing cell lysis (Moghadamtousi et al., 2014). The microbial count, $\mathrm{pH}$, and organoleptic evaluation revealed that $5 \%$ turmeric extract could extend the shelf life upto five days of Presto of Lalawak fish (Barbodes balleroides) when stored at room temperature (Aulia et al., 2019). While studying the rainbow trout fillets coated with turmeric, quinoa (Chenopodium quinoa), cardamom (Elettaria cardamomum) and chitosan separately, Korkmaz et al. (2019) reported the highest inhibition of microbial spoilage in turmeric coated fillet. The turmeric coat 
decreased lipid oxidation and protein denaturation with low $\mathrm{pH}$ value. This resulted in lowest increase in total volatile basic nitrogen (TVB-N) among all the samples. Pezeshk et al. (2011) reported that dip treatment in turmeric extract, shallot extract, and their combination separately of rainbow trout (Oncorhynchus mykiss) under vacuum-packaged condition showed retardation of chemical changes (TVB$\mathrm{N}, \mathrm{PV}$, and TBA) with slowdown in microbial growth resulting in extended shelf life. Dip treatment in turmeric extract of cuttlefish (Sepia brevimana) stored at $4^{\circ} \mathrm{C}$ exhibited inhibitory activity against mesophilic, psychrophilic, Pseudomonas sp. and biogenic amine forming bacterial growth after 15 days of storage with 3 days more shelf life than the control (Arulkumar et al., 2017).

According to Jana and Chakraborti (2016) the protein denaturation in fish can be minimized even upto 15 days by applying salt and turmeric together which is nowadays practiced in domestic households too. Nahid et al. (2016) reported that using salt and turmeric mixture followed by smoke-drying of fish shortened the drying time, maintained nutritional qualities with extended shelf life. Turmeric and salt-treated sun-dried Shoal (Channa striatus), taki (Channa punctatus), and Tengra (Mystus tenagra) exhibited excellent sensory properties, less protein and fat deterioration with acceptable microbial load $\left(<10^{5} \mathrm{CFU} \mathrm{g}^{-1}\right)$ (Farid et al., 2016). At the end of 12 months of storage of sun-dried tengra (Mystus tengara), both salt and turmeric treated fish remained in acceptable condition, whereas fish treated only with salt became spoiled based on the values of TVBN, pH and free fatty acid (Farid et al., 2015).

Similarly, turmeric and salt-treated sundried shoal (Channa striatus) showed better nutrition profile, organoleptic properties, and higher shelf life than the fish undergoing the same treatment but without turmeric (Farid et al., 2014). Ummul-Izzatul et al. (2020) reported that turmeric-salt marinated mackerel (Rastrelliger brachysoma) exhibited lowered growth of $L$. monocytogenes with a reduction of $0.07 \mathrm{log} \mathrm{CFU} / \mathrm{g}$ from $2.81 \mathrm{log} \mathrm{CFU} / \mathrm{g}$ under isothermal storage temperature. Imtiaz et al. (2017) reported that ribbon fish (Trichiurus haumela) treated with turmeric and dried in sun showed lower bacterial load than the salttreated samples and control. Mosarrat et al. (2017) reported that salt and turmeric treated smoke-dried Gudusia chapra, Xenentodon cancila, and Macrognathu spancalus resulted in good sensory, proximate, chemical, and nutritional quality with lesser microbial load. On the other hand, Pankyamma et al. (2016) observed remarkably lesser values in FFA, peroxide value (PV) and thiobarbituric acid reactive substance (TBARS) in dip treated sutchi catfish fillets in $2 \%$ turmeric solution and smoked at $60^{\circ} \mathrm{C}$ for 2 hours than the control.

Handayani et al. (2018) reported the effectiveness of a combination of 3 to $6 \%$ of turmeric and 2 to $4 \%$ of tamarind in the preservation of yellow seasoned pindang fish by reducing microbial load. Chilek et al. (2017) found the best preservative effect of a combination of salt, and turmeric and sodium acetate applied to preserve refrigerated tilapia fish. Patin fillets coated with Cassava starch, enriched with Javanese turmeric and red ginger essential oil showed retardation in microbial growth, inhibited protein deterioration, and slowed down lipid oxidation while storing under the frozen condition for four months (Utami, 2016). Fish treated with salt, pepper, turmeric, and ajwain sample conferred best nutritional profile, better organoleptic properties, delaying in microbial spoilage, and enzymatic activity with extended shelf life (Alex, 2016). Treatment with $0.3 \%$ of salt and $0.15 \%$ of curcumin with a soaking time of 20 minutes followed by drying at $40^{\circ} \mathrm{C}$ for $20 \mathrm{~h}$ of snake head (Channa striata) exhibited nice physicochemical, microbiological, and organoleptic characteristics (Minh et al., 2019).

Antifungal activity of turmeric in fish: Curcumin, the most important component of turmeric showed anti-fungal activity against various fungi. The most possible mechanism may be due to decrease in ergosterol content in 
fungal cell in presence of curcumin. Curcumin reduces the ergosterol production and leads to accumulations of biosynthetic precursors of ergosterol. This eventually results in cell death due to the production of reactive oxygen spices (Sharma et al., 2010). The fungal inhibition may also be due to a decrease in the proteinase secretion as well as alteration of the membraneassociated properties of ATPase activity (Neelofar et al., 2011).

Curcumin has antifungal activities against 38 different strains of genus Candida including C. albicans, C. glabrata, C. krusei, $C$. tropicalis, and $C$. guilliermondii causing fish disease; the mechanism may be due to intracellular acidification through $\mathrm{H}^{+} /$ extrusion inhibition (Moghadamtousi et al., 2014). Turmeric oil is found to have significant antifungal activity against Aspergillus flavus (Kumar et al., 2011) that produces aflatoxin causing harmful effects to fish culture (Sivaraman et al., 2016; Mohamed et al., 2017).

Antioxidant activity of turmeric in fish: The presence of antioxidants significantly retards the rate of oxidation by protecting cells from damage caused due to unstable free radicals (Asimi et al., 2013). The curcumin can scavenge oxygen from these free radicals. This property increases when phenolic and methoxy groups are present in the ortho position of curcumin (Niranjan and Prakash, 2008). The lipid peroxidation product, thiobarbituric acid reactive substances (TBARS) content either reduced or remains unaltered in Anabas testudineus fed with turmeric supplemented diet as reported by Manju et al. (2012). Turmeric decreased the enhanced frequency of micronuclei induction in peripheral erythrocytes induced by chromium trioxide in Channa punctatus (Prasad et al., 2017).

Insecticidal activity of turmeric in fish: Blowflies and insect infestation are one of the major problem associated with fish drying. Turmeric powder showed inhibition against
Necrobia rufipes in dried punti fish (Ahmed et al., 2013).

\section{Conclusions}

Recently there is a high demand among the consumers for fish having great quality and safety, presence of a minimal amount of less harmful preservatives, low cost, and the absence of pollutants, antibiotics, and carcinogens. In order to achieve improved food safety and to harmonize consumer demands with the necessary safety standards, traditional means of controlling microbial spoilage and hazards in foods, as well as the use of harmful chemical preservatives, are being replaced by combinations of innovative technologies that include natural antimicrobial substance, free of potential health hazards; such as turmeric. Turmeric has a magnificent history of use in Ayurveda, Unani, and Siddha system. Literature survey shows that turmeric possesses excellent antimicrobial, immunostimulatory, antioxidant, anti-fungal properties, and flavorenhancing attribute, thus increasing its potential to be used in fish preservation providing low cost and nutritious fish and fishery products with extended shelf life and minimal toxicity. Turmeric-preservation may be effectively used in combination with other preservative factors (hurdles) to inhibit microbial growth and achieve food safety. Using an adequate mix of hurdles is not only economically attractive; it also serves to improve microbial stability and safety, as well as the sensory and nutritional qualities of a food, which are required to be duly investigated.

Conflict of interest: Authors have no conflict of interest in this study.

Author's contribution: SN and PC: Collected the literatures cited here and wrote the first draft, arranged the final manuscript, and refined at per the journal guidelines; SC: Helped in collection of literatures; NR and SM: Helped in final refinement of the manuscript. 


\section{REFERENCES}

Ahmed H, Ahmed KN, Khanom NP and Noor P, 2013. Damage Potential and control measures of Necrobia rufipes (De Geer) (Coleoptera: Cleridae) on dry fish with plant materials. Bangladesh J Sci Ind Res, 48(1): 19-24, doi: 10.3329/bjsir.v48i1.15409

Akbik D, Ghadiri M, Chrzanowski W and Rohanizadeh R, 2014. Curcumin as a wound healing agent. Life Sci, 116(1): 1-7, doi: 10.1016/ j.lfs.2014.08.016

Akram M, Shahab-Uddin, Afzal A, Khan U, Abdul H et al., 2010. Curcuma longa and Curcumin: A review article. Rom J Biol Plant Biol, 55(2): 65-70

Alex T, 2016. Effect of spices and herb for enhancing microbial quality and shelf life of dried Indian oil sardine (Sardinella longiceps) fish during storage at room temperature. IOSR J Environ Sci Toxicol Food Technol, 10(1): 44-51, doi: 10.9790/2402-10124451

Amalraj A, Pius A, Gopi S and Gopi S, 2017. Biological activities of curcuminoids, other biomolecules from turmeric and their derivatives. A review. J Tradit Complement Med, 7(2): 205233, doi: 10.1016/j.jtcme.2016.05.005

Antunes SA, Rolazza WS, Schittler L and Gomes GA, 2012. Synergistic and antimicrobial properties of commercial turmeric (Curcuma longa L.) essential oil against pathogenic bacteria. Food Sci Technol, 32(3): 7- 11, doi: 10.1590/S0101-2061201200 5000082

Arulkumar A, Ramanchandran K, Paramasivam S, Palanivel R and Miranda JM, 2017. Effects of turmeric (Curcuma longa) on shel-life extension and biogenic amine control of cuttlefish (Sepia brevimana) during chilled storage. CyTA J Food, 5(3): 441-447, doi: 10.1080/19476337.2017. 1296495

Arunkumar P, Ramasubramanian V and Munirasu S, 2016. Effect of Curcuma Longa enriched Mesocylops thermocyclopoides on freshwater fish, Cyprinus carpio. Int J Res Dev Pharm Life Sci, 6(1): 2484-2492

Asimi OA, Sahu NP and Pal AK, 2013. Antioxidant activity and antimicrobial property of some Indian spices. Int J Sci Res Publ, 3(3): 1-8

Aulia S, Rostini I, Junianto J and Pratama RI, 2019. Additions of extract turmeric on the presto of Lalawak fish (Barbodesballeroides) stored at room temperature. World Sci News, 134(2): 63-73

Bakli S, Nath S, Chowdhury S and Pati K, 2020. Surimi powder: processing technology and potential application. J Entomol Zool Stud, 8(4): 850-859
Bhowmik D, Chiranjib, Kumar KPS, Chandira M and Jayakar B, 2009. Turmeric: A herbal and traditional medicine. Arch Appl Sci Res, 1(2): 86-108

Chilek TZT, Amin AM, Jusoh N, Hanidun SM, Suhaimin N et al., 2017. Effect of sodium acetate, chilli and turmeric on the shelf life of refrigerated tilapia fillet. Malays Appl Biol J, 46(3): 51-58

Chong CY, Abu Bakar F, Russly AR, Jamilah B and Mahyudin NA, 2011. The effects of food processing on biogenic amines formation. Int Food Res J, 18(3): 867-876

Farid FB, Latifa GA, Chakraborty SC, Nahid MN and Begum M, 2015. Protective effect of salt (sodium chloride) and turmeric (Curcuma longa) on physicochemical attributes of sun-dried Tengra fish (Mystus tengra; Hamilton-Buchanan, 1822) at Laboratory condition. Int Res J Biol Sci, 4: 33-40

Farid FB, Latifa GA, Chakraborty SC, Nahid MN and Begum M, 2016. Combine effect of Curcuma longa (turmeric) powder and dry-salt with sundrying in quality changes of three freshwater fish species of Meghna River. European J Biotechnol Biosci, 4(10): 42-47

Farid FB, Latifa GA, Nahid MN and Begum M, 2014. Effect of sun-drying on proximate composition and $\mathrm{pH}$ of shoal fish (C. striatus, Bloch, 1801) treated with salt and salt-turmeric storage at room temperature $\left(27^{\circ} \mathrm{C}-30^{\circ} \mathrm{C}\right)$. J Vet Med Anim Sci, 7(9): 01-08, doi: 10.9790/2380-07930108

Ghaly AE, Dave D, Budge S and Brooks MS, 2010. Fish spoilage mechanisms and preservation techniques. Am J Appl Sci, 7(7): 859-877, doi: 10.3844/ajassp.2010.859.877

Gopinath H and Karthikeyan K, 2018. Turmeric: A condiment, cosmetic and cure. Indian J Dermatol Venereol Leprol, 84(1): 16-21, doi: 10.4103/ ijdvl.IJDVL_1143_16

Handayani BR, Dipokusumo B, Werdiningsih W, Rahayu TI and Sugita DL, 2018. Microbial quality of yellow seasoned 'pindang' fish treated with turmeric and tamarind. IOP Conf Ser Earth Environ Sci, 102(1): 1-9, doi: 10.1088/1755-1315/ 102/1/012019

Ikpeama A, Onwuka GI and Nwankwo C, 2014. Nutritional composition of Tumeric (Curcuma longa) and its antimicrobial properties. Int J Sci Eng Res, 5(10): 1085-1089

Imtiaz MM, Haque SA, Sarker MR, Mufty MM, Ali MM et al., 2017. Quality assessment of improved sun-dried ribbon fish (Trichiurus haumela) by salt and turmeric powder treatment. Int J Adv Chem 
Eng Biol Sci, 4(1): 162-167, doi: 10.15242/ IJACEBS.R1

Jana U and Chakrabarti S, 2016. Comparison of restoration of protein contents of preserved Rohu (Labio rohita), treated under different cooking conditions. Int J Sci Res, 5(3): 1374-1377

Kaur S, Modi NH, Panda D and Roy N, 2010. Probing the binding site of curcumin in Escherichia coli and Bacillus subtilis Fts Z - A structural insight to unveil antibacterial activity of curcumin. Eur $\mathbf{J}$ Med Chem, 45(9): 4209-4214, doi: 10.1016/ j.ejmech.2010.06.015

Korkmaz F, Parlak V, Kaynar Ö, Uçar A, Alak G et al., 2019. Effect of natural preservatives on protein degradation, microbiological and chemical alterations in rainbow trout fillets. Pak J Zool, 51(2): 405-412, doi: 10.17582/journal.pjz/ 2019.51.2.405.412

Krup V, Prakash LH and Harini A, 2013. Pharmacological activities of turmeric (Curcuma longa linn): A Review. J Homeopathy Ayurveda Med, 2: 133

Kumar A, Dora J and Singh A, 2011. A review on spice of life Curcuma longa (turmeric). Int J Appl Biol Pharm Technol, 2: 371-376

Lawhavinit O, Kongkathip N and Kongkathip B, 2010. Antimicrobial activity of curcuninoids from Curcuma longa L. on pathogenic bacteria of shrimp and chicken. Kasetsart J (Nat Sci), 44(3): 364-371

Manju M, Akbarsha MA and Oommen OV, 2012. In vivo protective effect of dietary curcumin in fish Anabas testudineus (Bloch). Fish Physiol Biochem, 38(2): 309-318, doi: 10.1007/s10695-011-9508-x

Mei U, Ma X and Xie J, 2019. Review on natural preservatives for extending fish shelf life. Foods, 8(10): 490, doi: 10.3390/foods8100490

Minh NP, Vo TT, Hoai TTN, Khang HD, Hong TC et al., 2019. Production of honey-curcumin-drysalted snakeheah fish (Channa striata). Int J Pharm Sci Res, 11(4): 1410-1415

Moghadamtousi SZ, Abdul HA, Hassandarvish P, Tajik $\mathrm{H}$, Abubakar S et al., 2014. A review on antibacterial, antiviral, and antifungal activity of curcumin. Biomed Res Int, 2014: 186864, doi: 10.1155/2014/186864

Mohamed HMA, Walaa FAE, Braeuning A and Hammad S, 2017. Detection of aflatoxin producing fungi isolated from tilapia and fish feed. EXCLI J, 16: 1308-1318, doi: 10.17179/ excli2017-960

Mohan CO, 2018. Thermal processing of fishery products. ITEC training programme on 'Protocols for the Production of High Value Secondary Products from Industrial Fish and Shellfish Processing' from 25/11/2019 to 21/12/2019 at ICAR-CIFT, Kochi, pp 87-98

Mooraki N, Batmany Y, Zoriehzahra SJ and Kakoolaki S, 2019. Evaluating the effect of using turmeric (Curcuma longa) on growth performance and hematological parameters of the ornamental fish, Green Terror (Andinocara rivulatus). J Surv Fish Sci, 5(2): 37-47, doi: 10.18331/SFS2019.5.2.5

Mosarrat NN, Gulshan AL, Chakraborty SC, Begum M and Farid FB, 2017. Effect of salt and turmeric treated smoke-drying method on the sensory, proximate, chemical, and microbial quality of $G$. chapra, X. cancila and $M$. pancalus fish. Int $\mathrm{J}$ Adv Educ Res, 2(1): 20-25

Mukherjee S, Nath S, Chowdhury S and Chatterjee P, 2020. Antimicrobial activity of garlic (Allium sativum) and its potential use in fish preservation and disease prevention. Int J Microbiol Res, 12(7): 1879-1883

Mukhtar S and Ghori I, 2012. Antibacterial activity of aqueous and ethanolic extracts of garlic, cinnamon, and turmeric against Escherichia coli ATCC 25922 and Bacillus subtilis DSM. Int J Appl Biol Pharm Technol, 3(2): 131-136

Mun SH, Kim SB, Kong R, Choi JG, Kin YC et al., 2014. Curcumin reverse methicillin resistance in Staphylococcus aureus. Molecules, 19(11): 18283-18295, doi: 10.3390/molecules191118283

Nahid MN, Latifa GA, Chakraborty SC, Farid FB and Begum M, 2016. Investigation of physic-chemical and microbial quality of two smoke-dried freshwater fish species; Chapila (Gudusia chapra) and Baim (Mastacembelus pancalus) treated with saltturmeric solution storage at room temperature (26-31 ${ }^{\circ} \mathrm{C}$ ). Int J Multidiscip Res Dev, 3(1): 217-222

Nath S, Chowdhury S and Dora KC, 2017. Effect of Bacillus subtilis FPTB23 on behaviour of Enterococcus faecalis in vacuum-packed Asian Sea-Bass fillets at $5 \pm 1^{\circ} \mathrm{C}$. J Agric Eng Food Technol, 4(1): 31-36

Nath S, Chowdhury S, Dora KC and Sarkar S, 2014. Role of biopreservation in improving food safety and storage. Int J Eng Res Appl, 4: 26-32

Nath S, Chowdhury S, Sarkar S and Dora KC, 2013. Lactic acid bacteria - A potential biopreservative in sea food industry. Int J Curr Adv Res, 1(6): 471-475

Nath S, Chowdhury S and Singh AK, 2019. Icing of fish: A way to retain nutritional quality and food safety. J Entomol Zool Stud, 7(4): 474-478

Neelofar K, Shreaz S, Rimple B, Muralidhar S, Nikhat M 
et al., 2011. Curcumin as a promising anticandidal of clinical interest. Can J Microbiol, 57(3): 204-210, doi: 10.1139/W10-117

Niranjan A and Prakash D, 2008. Chemical constituents and biological activities of turmeric (Curcuma longa) - A review. J Food Sci Technol, 45(2): 109-116

Nwaigwe U, 2017. Fish preservation and processing. CyTAJ Food Sci, 1: 1-31

Pankyamma V, Somarajan T, Ninan G, Velayudhanelayodam LK, Aliyamveettil ZA et al., 2016. Effects of turmeric treatment and smoking duration on the shelf life of ready to cook fillets from sutchi catfish during chill storage. J Food Process Eng, 39(5): 472-483, doi: 10.1111/jfpe.12238

Pezeshk S, Rezaei M and Hosseini H, 2011. Effects of turmeric, shallot extracts, and their combination on quality characteristics of vacuum-packaged rainbow trout stored at $4 \pm 1^{\circ} \mathrm{C}$. J Food Sci, 76(6): 387-391, doi: 10.1111/j.1750-3841.2011.02242.x

Prasad R, Kumar M and Trivedi SP, 2017. Antigenotoxic effect of turmeric powder extract curcumin against chromium trioxide induced genotoxicity in fish Channa punctatus. J Entomol Zool Stud, 5(1): 89-94

Rathaur P, Waseem R, Ramteke PW and John SA, 2012. Turmeric: The golden spice of life. Int J Pharm Sci Res, 3(7): 1987-1994, doi: 10.13040/IJPSR.09758232.3(7).1987-94

Septiana E, Sukarno N, Sukarno and Simanjuntak P, 2017. Endophytic fungi associated with turmeric (Curcuma long a L.) can inhibit histamine-forming bacteria in fish. HAYATI J Biosci, 24(1): 46-52, doi: 10.1016/j.hjb.2017.05.004

Sharma M, Manoharlal R, Puri N and Prasad R, 2010. Antifungal curcumin induces reactive oxygen species and triggers an early apoptosis but prevents hyphae development by targeting the global repressor TUP1 in Candida albicans. Biosci Rep, 30(6): 391-404, doi: 10.1042/BSR20090151

Sivaraman GK, Visnuvinayagam S and Jha AK, 2015. Microbiological spoilage of dried fishes. Available at SSRN 2709070: 1-5

Sivaraman GK, Visnuvinayagam S, Jha AK, Remya S,
Renuka V et al., 2016. Molecular divergence and identification of Aspergillus species in dry fishes of Gujarat India. Proceedings of the National Academy of Sciences, India Section B: Biological Sciences, 88(2), pp 505-515

Sodamola MO, Jimoh WA, Adejola YA, Akinbola DD, Olanrewaju A et al., 2016. Effect of turmeric (Curcuma longa) root powder (TRP) on the growth performance, hematology and serum biochemistry of African catfish (Clarias gariepinus). Acad J Agric Res, 4(9): 593-596

Sugiharto I, Widiastuti E and Prabowo NS, 2011. Effect of turmeric extract on blood parameters, feed efficiency and abdominal fat content in broilers. J Indones Trop Anim Agric, 36(1): 21-26, doi: 10.14710/jitaa.36.1.21-26

Suvarna R, Bhat SS and Hegde KS, 2014. Antibacterial activity of turmeric against Enterococcus faecalisAn in vitro study. Int J Curr Microbiol Appl Sci, 3(2): 498-504

Teow SY, Liew K, Ali SA, Khoo AS and Peh SC, 2016. Antibacterial action of curcumin against Staphylococcus aureus: A brief review. J Trop Med, 2016: 2853045, doi: 10.1155/2016/ 2853045

Ummul-Izzatul Y, Nor-Khaizura MAR, Ghazali FM, Son R, Shafiqa-Atikah MK et al., 2020. Survival of Listeria monocytogenes in turmeric-salt marinated short mackerel (Rastrelliger brachysoma) under isothermal storage temperature. Food Res, 4(Suppl 2): 48-56, doi: 10.26656/fr.2017.4(S2).S06

Utami R, 2016. Preservation effect of Javanese turmeric and red ginger essential oils on coated frozen patin fillets. Nusantara Biosci, 8(2): 264-267, doi: 10.13057/nusbiosci/n080220

Viji P, Venkateshwarlu G, Ravishankar C and Gopal TS, 2017. Role of plant extracts as natural additives in fish and fish products - A Review. Fish Technol, 54: 145-154

Yadav RP, Tarun G, Roshan C and Yadav P, 2017. Versatility of turmeric: A review the golden spice of life. J Pharmacogn Phytochem, 6(1): 41-46

Received - 26.09.2021, Accepted-20.11.2021, Published-01.12.2021

Section Editor: Prof. S. K. Das, Member, Editorial Board 